\title{
PENGARUH MEDIA PEMBELAJARAN DAN GAYA BELAJAR TERHADAP HASIL BELAJAR IPS TERPADU SISWA KELAS VIII SMP NEGERI 1 BADAR DAN SMP NEGERI 5 BADAR KAB. ACEH TENGGARA
}

\author{
Sri Rahmawati ${ }^{1}$, Baharuddin ${ }^{2}$ \\ Teknologi Pendidikan Pascasarjana Universitas Negeri Medan \\ Srimilaselian@.gmail.com ${ }^{1}$
}

\begin{abstract}
Abstrak: Penelitian ini bertujuan untuk mengetahui dan mendeskripsikan pengaruh hasil belajar IPS siswa dengan menggunakan media pembelajaran animasi dan media pembelajaran gambar diam, untuk mengetahui dan mendeskripsikan pengaruh hasil belajar IPS siswa yang memiliki gaya belajar visual dan gaya belajar auditori, untuk mengetahui dan mendeskripsikan interaksi antara media pembelajaran dan gaya belajar terhadap hasil belajar IPS siswa. Sebelum tes hasil belajar digunakan untuk menguji hipotesis terlebih dahulu tes diujicobakan untuk mengetahui tingkat validitas dan reliabilitas tes. Hipotesis penelitian diuji dengan menggunakan Anava 2 jalur dimana sebelumnya dilakukan uji persyaratan data yaitu uji normalitas dan uji homogenitas. Hasil penelitian disimpulkan sebagai berikut; media pembelajaran animasi lebih baik diterapkan pada siswa yang memiliki gaya belajar visual sedangkan media pembelajaran gambar diam akan lebih baik diterapkan pada siswa yang memiliki gaya belajar auditori serta terdapat interaksi antara media pembelajaran dan gaya belajar dalam mempengaruhi hasil belajar siswa.
\end{abstract}

\section{Kata Kunci: Media Pembelajaran, Gaya Belajar Dan Hasil Belajar}

\begin{abstract}
This research aims to identify and describe the effect of social sciences students learning outcomes who applied animation instructional media and still image instructional media, to identify and describe the effect of social sciences students learning outcomes who have visual learning styles and auditory learning styles to identify and describe the interaction between instructional media and learning styles toward social sciences students learning outcomes. Before the treatment was given, for the first the sample given a test to differentiate the learning style of students achievement. Before the achievement test used to test the hyphoteses, the test tested to determine the level of validity and reliability of the test. The research hyphoteses tested by using Anava 2 tails where previous test data requirements that normality test and homogenity test. The conclusion of this research are; animation instructional media better to applied to students who have a visual learning style while instructional media still images would be better applied to students who have auditory learning style and there is interaction between instructional media and learning styles toward student learning outcomes.
\end{abstract}

Keyword: Instructional Media, Learning Styles, Students Achievement

\section{PENDAHULUAN}

Peningkatan mutu pendidikan,
merupakan prioritas utama dalam pengembangan pendidikan saat ini. Beberapa upaya yang dilakukan pemerintah dalam rangka mencapai tujuan tersebut adalah dengan peningkatan sumber daya manusia maupun sumber daya non manusia. Salah satu di antaranya adalah peningkatan proses pembelajaran. Proses pembelajaran adalah sebuah sistem karena dapat dipastikan bahwa sumber keberhasilan pembelajaran di sekolah terkait dengan sejumlah komponen yang terlibat di dalamnya. Komponen yang dimaksud adalah kurikulum, strategi, guru, media, metode, siswa serta yang melingkupi proses pembelajaran dan pendidikan itu sendiri.

Penggunaan media pembelajaran perlu dipertimbangkan dalam proses pembelajaran karena media pembelajaran sangat menentukan dalam penguasaan materi yang diajarkan karena media pembelajaran dapat meningkatkan hasil belajar siswa. Muhadi (2008:5) mengatakan bahwa media sangat dibutuhkan dalam proses pembelajaran karena media merupakan bahasa guru untuk menyampaikan maksud dan perasaan guru kepada siswa. Lebih lanjut Muhadi (2008:5) mengemukakan bahwa siswa akan lebih mudah dan cepat mengerti apa yang disampaikan oleh guru jika guru tersebut 
menggunakan media saat proses pembelajaran berlangsung. Begitu juga dengan pemilihan strategi pembelajaran yang tepat juga sangat mempengaruhi keberhasilan siswa dalam menguasai materi pelajaran. J.R. David (Gulo ; 2008:8) mengemukakan ialah plan, methode, or series achtivities designed to achieves a particular educational. Menurut pengertian ini strategi belajar mengajar meliputi rencana, metode, dan perangkat kegiatan yang direncanakan untuk mencapai tujuan pengajaran tertentu.

Hal ini dapat dilihat dari data dinas pendidikan Kabupaten Aceh Tenggara tiga tahun terakhir yaitu tahun 2012/2013 dengan nilai ratarata 6,50 tahun 2013/2014 dengan nilai rata-rata 6,50 tahun 2014/2015 dengan nilai rata-rata 6,60 nilai tersebut masih dibawah KKM yaitu 7,00. Hal ini menunjukan masih rendahnya kemampuan siswa terhadap mata pelajaran IPS Terpadu yang menyebabkan hasil belajar siswa belum sesuai seperti apa yang diharapkan.

Maslow (1954) dan Mc Clelland (1949) faktor yang mempengaruhi keberhasilan adalah faktor internal dan eksternal siswa. Adapun faktor yang termasuk ke dalam faktor internal siswa yaitu kebutuhan fisiologis, rasa aman, sosial, kognitif (berperestasi), estetika, aktualisasi diri, sedangkan faktor eksternal siswa yaitu berasal dari guru dalam proses pembelajaran.

Selanjutnya secara khusus data yang diperoleh dari sekolah yang direncanakan dijadikan lokasi penelitian yaitu SMPN 1 dan SMPN 5 Badar Kabupaten Aceh Tenggara menunjukan, bahwa rata-rata nilai ujian sekolah mata pelajaran IPS Terpadu dari tahun 2012/2013 dengan nilai rata-rata 6,50 tahun 2013/2014 dengan nilai rata-rata 6,45 dan akhir tahun 2014/2015 dengan nilai rata-rata 6,50 nilai tersebut masih dibawah nilai KKM. Hal ini menunjukan bahwa rendahnya kemampuan mata pelajaran IPS Terpadu yang menyebabkan hasil belajar siswa pada mata pelajaran ini belum sesuai harapan.

Dari hasil observasi ditemukan bahwa ada kesenjangan yang terjadi di lapangan yang membuat proses pembelajaran di dalam kelas tidak berlangsung dengan efektif dan efesien. Untuk mengatasi kesenjangan tersebut perlu diidentifikasi faktor permasalahan yang menjadi penyebab kesenjangan itu terjadi. Dengan kata lain, prinsip kerjasama dalam kelompok kurang diperhatikan. Jika dilakukan kerjasama kelompok umumnya yang terjadi adalah siswa yang berprestasi lebih tinggi yang dominan untuk menguasai materi yang diberikan, sedangkan siswa yang berprestasi rendah kurang aktif dan terkesan hanya sebagai penonton saja selama kerjasama dalam kelompok dilakukan. Padahal agar kelas menjadi lebih produktif, dalam pembelajaran sangat diperlukan kerjasama antara sesama anggota kelompok yang memiliki latar belakang pengetahuan yang berbeda dalam memecahkan berbagai permasalahan.

Menurut Ahmadi (2003:46), faktor utama penyebab pembelajaran di dalam kelas tidak efektif adalah penggunaan media dan strategi pembelajaran yang tidak tepat. Pembuatan media pembelajaran yang tepat menurut Sardiman (1993:24) akan dapat mengatasi masalah sikap pasif siswa yang pada akhirnya menimbulkan kegairahan dalam belajar dan memungkinkan siswa untuk belajar sendiri. Beragam proses dan aspek pengetahuan siswa dalam kelas dapat dikembangkan guru dengan cara menawarkan media dan strategi pembelajaran yang berbeda-beda.

Arsyad (2001:15) mengatakan bahwa dalam proses belajar mengajar, ada dua hal yang perlu diperhatikan yaitu strategi pembelajaran dan media pembelajaran. Kedua aspek ini sangat berkaitan, di mana pemilihan salah satu strategi pembelajaran akan mempengaruhi jenis media pembelajaran yang sesuai sehingga dapat menciptakan pembelajaran menjadi efektif. Natawijaya dan Moesa (1992) juga mengatakan untuk menciptakan suasana pendidikan yang efektif diperlukan memadai, dan teknik penyajian menarik dengan memilih strategi belajar yang tepat.

Nurhadi (2005:34) mengatakan bahwa kebanyakan guru di Indonesia masih cenderung menggunakan strategi pembelajaran ekspositori yakni strategi pembelajaran yang beorienasti pada guru. Masih banyak guru beranggapan bahwa strategi ekspositori lebih baik dari strategi yang lain.

Berdasarkan paparan latar belakang di atas, penulis merasa perlu mengangkat permasalahan yang ada ke dalam suatu bentuk penelitian dengan judul " Pengaruh Media Pembelajaran dan Gaya Belajar Terhadap Hasil Belajar IPS Terpadu Siswa Kelas VIII SMPN 1 Badar dan SMPN 5 Badar Kab. Aceh Tenggara “. 
Menurut Surya dalam Rusman (2012 : 85) belajar dapat diartikan sebagai suatu proses yang dilakukan oleh individu untuk memperoleh perubahan perilaku baru secara keseluruhan, sebagai hasil dari pengalaman individu itu sendiri dalam berinteraksi dengan lingkungannya. Menurut Dimyati dan Mudjiono dalam Sagala ( $2005: 13$ ) mengemukakan siswa adalah penentu terjadinya atau tidak terjadinya proses belajar.

Corbanch dalam Rusman (2012 : 86) berpendapat bahwa 'learning is shown by change in behavior as a result of experience. Belajar sebagai suatu aktivitas yang ditunjukkan oleh perubahan tingkah laku sebagai hasil pengalaman. Makna dari defenisi yang dikemukakan oleh Corbanch lebih dalam lagi, bahwa belajar bukanlah semata-mata perubahan dan penemuan, tetapi sudah mencakup kecakapan yang dihasilkan akibat perubahan dan penemuan tadi. Setelah terjadi perubahan dan menemukan sesuatu yang baru, maka akan timbul suatu kecakapan yang memberikan manfaat bagi kehidupannya. Intinya belajar adalah out come. Senada dengan itu, teori behavioristik menyatakan bahwa belajar adalah perubahan tingkah laku sebagai akibat dari adanya interaksi antara stimulus dan respon. Dengan kata lain belajar merupakan bentuk perubahan yang dialami oleh siswa dalam hal kemampuan untuk bertingkah laku deng: yang baru sebagai hasil interaksi antara st dan respon (dalam Asri, 2005:64).

Sedangkan Romiszowski mengatakan bahwa hasil belajar ditunjukkan dalam bentuk penegtahuan dan keterampilan. Pengetahuan dikelompokkan dalam empat kategori, yaitu fakta, konsep, prosedur, dan prinsip. Fakta merupakan pengetahuan tentang objek nyata, asosiasi, kenyataan dan informasi verbal dari suatu objek. Konsep adalah pengetahuan tentang seperangkat objek konkrit atau defenisi. Prosedur merupakan pengetahuan tentang tindakan yang bersifat linier dalam mencapai tujuan. Selanjutnya prinsip adalah pernyataan mengenai hubungan dari dua konsep atau lebih.

Reigeluth (1983) mengemukakan bahwa hasil belajar merupakan salah satu aspek pengajaran yang dibagi menjadi tiga jenis yaitu : (1) keefektifan pengajaran yang diukur dengan tingkat pencapaian si belajar pada tujuan atau isi bidang studi yang telah ditetapkan, (2) efesiensi pengajaran diukur dengan rasio antara keefektifan dan jumlah waktu yang dipakai si belajar dan atau jumlah biaya pengajaran yang digunakan, dan (3) daya tarik pengajaran yang diukur dengan mengamati kecendrungan siswa untuk tetap belajar (dalam Degeng, 2000:15).

Senada dengan itu, Degeng (2000:23) menyatakan hasil pengajaran atau hasil belajar adalah semua efek yang dapat dijadikan sebagai indikator tentang nilai dari penggunaan metode pengajaran di bawah kondisi yang berbeda. Efek ini bisa berupa efek yang disengaja dirancang; karena itu ia efek yang diinginkan, dan bisa juga berupa efek yang nyata sebagai hasil penggunaan metode pengajaran tertentu. Sementara Joice dan Well (1980 : 1986) mengacukan hasil belajar atau pengajaran langsung instrukctional effects, dan pengajaran yang terbentuk secara kumulatif disebutnya sebagai nurturant effects. Hasil belajar diukur setelah siswa mengikuti semua kegiatan pembelajaran dengan tes hasil belajar.

$$
\text { Menurut Bloom }
$$

mengklasifikasikan hasil belajar menjadi tiga, yaitu : (1) kognitif, (2) afektif, (3) psikomotori. Menurut Bloom dalam Rusman (2012 : 126) ranah kognitif menggolongkan dan mengurutkan keahlian berpikir yang menggambarkan tujuan yang diharapkan. Proses berpikir mengekspresikan tahap-tahap kemampuan yang harus siswa kuasai, sehingga dapat menunjukkan kemampuan mengolah pikirannya sehingga mampu mengaplikasikan teori ke dalam perbuatan. Konsep tersebut mengalami perbaikan seiring dengan perkembangan dan kemajuan ilmu pengetahuan dan ilmu teknologi. Merill (1983) dalam Degeng (1986:15). mengklasifikasikan hasil belajar menjadi dua dimensi: tingkat unjuk kerja dan tipe isi. Klasifikasi ini hanya diterapkan dalam belajar ranah kognitif. Dimensi tingkat unjuk kerja dibagi menjadi tiga yaitu: (1) mengingat, (2) menggunakan, menemukan. Sedangkan tipe isi pengajaran dibedakan menjadi empat yaitu : (1) fakta, (2) konsep, (3) prosedur, (4) prinsip.

Menurut Joni T.R (dalam Trianto, 2007:6) menerangkan bahwa pembelajaran terpadu merupakan sistem pembelajaran yang memungkinkan siswa, baik secara individual maupun kelompok, aktif mencari, menggali dan menemukan konsep serta prinsip keilmuan secara holistik, bermakna dan otentik. Hamalik dalam Arsyad (2007:16) mengemukan bahwa 
pemakaian media pembelajaran dalam proses belajar mengajar dapat membangkitkan keinginan dan minat yang baru, membangkitkan motivasi dan ransangan kegiatan belajar dan bahkan membawa pengaruh-pengaruh psikologis terhadap siswa. Penggunaan media pembelajaran pada tahap orientasi pembelajaran akan sangat membantu keefektifan proses pembelajaran dan penyampaian pesan dan isi pelajaran pada saat itu. Selain itu juga dapat meningkatkan pemahaman, menyajikan data dengan menarik dan terpercaya, memudahkan penafsiran data dan memadatkan informasi.

Miarso dalam Munadi (2008:4)
berpendapat bahwa media yang dirancang dengan baik dalam batas tertentu dapat merangsang timbulnya semacam dialog internal dalam diri siswa yang belajar. Dengan perkataan lain terjadi komunikasi antara siswa dengan media atau secara tidak langsung antara siswa dengan sumber pesan atau pendidik. Media berhasil membawakan pesan belajar bila kemudian terjadi perubahan kualitas dalam diri siswa. Kehadiran media akan membuat pendidik dapat meningkatkan minat siswa dalam proses belajar mengajar dan siswa dapat lebih cepat memahami dan mengerti terhadap materi yang disampaikan pendidik.

Sabri (2007:108) menyatakan bahwa fungsi dan nilai media terdiri atas enam fungsi yaitu (1) pengguna media dalam proses belajar mengajar mempunyai fungsi tersendiri sebagai alat bantu untuk mewujudkan situasi belajar mengajar yang efektif, (2) penggunaan media merupakan bagian yang integral dari keseluruhan situasi mengajar, (3) media dalam penggunaanya integral dengan tujuan yang ingin dicapai dan bahan pelajaran, (4) media bukan merupakan hiburan yang hanya sekedar melengkapi proses belajar mengajar, (5) penggunaan media dalam pembelajaran berfungsi untuk mempercepat dan membantu siswa dalam menangkap pengertian dan pemahaman dari proses pembelajaran, dan (6) media dalam pembelajaran diutamakan untuk meningkatkan dan mempertinggi mutu belajar. Kata media merupakan bentuk jamak dari kata medium yang berarti perantara atau pengantar terjadinya komunikasi dari pengirim menuju penerima. Media adalah berbagai jenis komponen dalam lingkungan siswa yang dapat merangsang untuk belajar. (Gagne dalam Daryanto, $2010: 157$ )
Pengertian Animasi Menurut Fernandes dalam bukunya Macromedia Flash Animation \& Cartooning: A creative Guide (http://ginafebriani.wordpress.com/), animasi definisikan sebagai berikut: "Animation is the process of recording and playing back a sequence of stills to achieve the illusion of continues motion" (Ibiz Fernandez McGrawHill/Osborn, California, 2002). De Porter dan Hernacki (2004) menyatakan bahwa "gaya belajar merupakan kombinasi dari bagaimana Anda menyerap, dan kemudian mengatur serta mengolah informasi". Drummond (dalam Ardi, 2007) mendefinisikan gaya belajar sebagai "an individual's preferred mode and desired conditions of learning." Sedangkan Nasution (2002) mengemukakan bahwa gaya belajar adalah cara yang dilakukan seseorang dalam menangkap stimulus dan informasi, cara mengingat berpikir dan memecahkan soal. Selanjutnya juga dikatakan bahwa gaya belajar ini berhubungan dengan proses-proses kemampuan yang dimiliki seseorang.

Gaya belajar mengacu pada cara belajar yang lebih disukai pembelajar. Umumnya, dianggap bahwa gaya belajar seseorang berasal dari variabel kepribadian, termasuk susunan kognitif dan psikologis latar belakang sosio cultural, dan pengalaman pendidikan. Keanekaragaman gaya belajar siswa perlu diketahui pada awal permulaannya diterima pada suatu lembaga pendidikan yang akan ia jalani. Hal ini akan memudahkan bagi pebelajar untuk belajar maupun pembelajar untuk mengajar dalam proses pembelajaran. Pembelajaran akan dapat belajar dengan baik dan hasil belajarnya baik, apabila ia mengerti gaya belajarnya. Hal tersebut memudahkan pembelajar dapat menerapkan pembelajaran dengan mudah dan tepat (Kolb: 1984).

Media pembelajaran yang baik harus dipilih berdasarkan karakteristik siswa seperti kemampuan awal, minat, dan kreativitas. Tujuan media pembelajaran adalah menciptakan suasana belajar yang menarik perhatian siswa. Media pembelajaran yang tepat akan meningkatkan hasil belajar siswa, sehingga kegagalan dalam proses belajar mengajar dapat diperkecil. Media yang digunakan dalam penelitian ini yaitu media animasi dan gambar diam.

Media animasi merupakan peralatan elektronik digital yang dapat memproses suatu masukan untuk menghasilkan suatu keluaran 
yang bekerja secara digital. Media animasi adalah hasil teknologi modern yang membuka kemungkinan-kemungkinan yang besar alat pendidikan.

Animasi merupakan gerakan objek maupun teks yang diatur sedemikian rupa sehingga menarik dan kelihatan lebih hidup. Selama ini animasi digunakan dalam media pembelajaran untuk alasan, pertama menarik perhatian siswa dan memperkuat motivasi. Animasi jenis ini biasanya berupa tulisan atau gambar yang bergerak yang dapat menarik perhatian siswa. Animasi ini biasanya tidak ada hubungannya dengan materi pelajaran. Fungsi yang kedua adalah sebagai sarana untuk memberikan pemahaman kepada murid atas materi yang diberikan. Membuat animasi untuk tujuan pembelajaran tidak sama dengan membuat animasi untuk sekedar hiburan. Dibutuhkan pengetahuan tentang bagaimana sebenarnya informasi yang disajikan lewat ilustrasi dinamis, diproses oleh kognitif otak manusia.

Sementara media gambar diam merupakan media visual yang berupa gambar yang dihasilkan melalui proses fotografi dan sejenisnya yang tidak dapat bergerak seperti foto, lukisan dan lain sebagainya.

Gambar diam merupakan sebagai tiruan barang, orang, binatang, tumbuhan, dan sebagainya yang dibuat dengan tinta, cat coret, potret, dan lainnya..Kegiatan pembelajaran berbasiskan teknologi komputer akan mengubah tuntutan peranan guru dalam pembelajaran. Guru tidak lagi bertindak sebagai penyampai materi, tetapi lebih bertindak sebagai fasilitator bagi siswa untuk menemukan konsep-konsep yang dipelajari, tentu saja dalam proses menemukan ini adalah proses menemukan kembali konsep yang telah ditemukan.

Media animasi yang digunakan dalam proses pembelajaran IPS Terpadu ternyata dapat meningkatkan hasil belajar siswa. Media pembelajaran animasi yang merupakan kumpulan gambar yang diolah sedemikian rupa sehingga menghasilkan gerakan dan dilengkapi dengan audio sehingga berkesan hidup serta menyimpan pesan-pesan pembelajaran. Media animasi pembelajaran ini dapat dijadikan sebagai perangkat pembelajaran yang siap kapan saja digunakan untuk menyampaikan materi pembelajaran. Kehadiran media animasi dalam pembelajaran IPS Terpadu sangat mendukung proses penyampaian berbagai informasi dari guru ke siswa. Pentingnya animasi sebagai media pembelajaran adalah memiliki kemampuan untuk memaparkan sesuatu yang rumit atau komplek serta sulit dijelaskan dengan hanya gambar atau kata-kata saja. Serta sebagai media ilmu pengetahuan, juga memiliki kemampuan untuk dapat memaparkan sesuatu yang rumit untuk dijelaskan hanya dengan gambar atau kata-kata saja.

Dengan kemampuan ini maka animasi dapat digunakan untuk menjelaskan suatu materi yang secara nyata tidak dapat terlihat oleh mata, dengan cara melakukan visualisasi maka materi yang dijelaskan dapat tergambarkan. Selain itu animasi sebagai media ilmu pengetahuan dapat dijadikan sebagai perangkat ajar yang siap kapan saja untuk mengajarkan materi yang telah dianimasikan, terutama dengan adanya teknologi interaktif pada saat ini baik melalui perangkat komputer ataupun perangkat elektronik lainnya. Berdasarkan pemikiran di atas diduga bahwa hasil siswa yang diajar menggunakan media animasi lebih tinggi daripada siswa yng diajar dengan menggunakan media gambar diam.

Rumusan masalah penelitian ini adalah: (1) Apakah hasil belajar IPS siswa yang diajar dengan media animasi lebih tinggi daripada siswa yang diajar dengan media gambar diam?; (2) Apakah hasil belajar IPS siswa yang memiliki gaya belajar visual lebih tinggi daripada siswa yang memiliki gaya belajar auditori?; dan (3) Apakah terdapat interaksi antara media pembelajaran dengan gaya belajar terhadap hasil belajar IPS siswa?

\section{METODE}

Penelitian ini dilaksanakan di SMPN 1 dan SMPN 5 Badar Kecamatan Badar Kabupaten Aceh Tenggara.. Perlakuan (treatment) penelitian dilaksanakan dengan menyesuaikan jadwal pelajaran IPS Terpadu. populasi dalam penelitian ini adalah seluruh siswa yang berada di kelas VIII SMPN 1 Badar dan SMPN 5. Setiap kelas mempunyai karakteristik yang sama, diantaranya siswa di setiap kelas tidak ada yang pernah tinggal kelas, siswa rata-rata memiliki umur yang tidak jauh berbeda, dan memakai kurikulum yang sama. 
Tabel 1. Desain Penelitian Faktorial 2x2

\begin{tabular}{|c|c|c|}
\hline \multirow{2}{*}{$\begin{array}{c}\text { Gaya Belajar } \\
\text { (A) }\end{array}$} & \multicolumn{2}{|c|}{ Media Pembelajaran (B) } \\
\cline { 2 - 3 } & Gambar Diam $\left(\mathrm{B}_{1}\right)$ & Animasi (B $\left.{ }_{2}\right)$ \\
\hline Visual $\left(\mathrm{A}_{1}\right)$ & $\mu \mathrm{A}_{1} \mathrm{~B}_{1}$ & $\mu \mathrm{A}_{1} \mathrm{~B}_{2}$ \\
\hline Auditori $\left(\mathrm{A}_{2}\right)$ & $\mu \mathrm{A}_{2} \mathrm{~B}_{1}$ & $\mu \mathrm{A}_{2} \mathrm{~B}_{2}$ \\
\hline
\end{tabular}

Keterangan :

$\mu \mathrm{A}_{1} \mathrm{~B}_{1}=$ Rata - rata hasil belajar siswa yang mempunyai gaya belajar visual dengan menggunakan media pembelajaran gambar diam

$\mu \mathrm{A}_{1} \mathrm{~B}_{2} \quad=$ Rata - rata hasil belajar siswa yang mempunyai gaya belajar visual dengan menggunakan media pembelajaran animasi

$\mu \mathrm{A}_{2} \mathrm{~B}_{1}=$ Rata - rata hasil belajar siswa yang mempunyai gaya belajar auditori dengan menggunakan media pembelajaran gambar diam $\mu \mathrm{A}_{2} \mathrm{~B}_{2}=$ Rata - rata hasil belajar siswa yang mempunyai gaya belajar auditori dengan menggunakan media pembelajaran animasi

Pengujian homogenitas dilakukan dengan kriteria : jika $F_{\text {hitung }}<F_{\text {tabel }}$ maka sampel berasal dari populasi yang homogen. Jika $\mathrm{F}_{\text {hitung }}>$ $\mathrm{F}$ tabel yang menyatakan bahwa sampel berasal dari populasi yang tidak homogen. Teknik analisis inferensial digunakan untuk menguji hipotesis penelitian dengan menggunakan teknik analisis varians (ANAVA) dua jalur. Sudjana (2002) menjelaskan sebelum ANAVA dua jalur dilakukan, terlebih dahulu ditentukan persyaratan analisis yakni persyaratan normalitas menggunakan uji Liliefors, sedangkan untuk uji persyaratan homogenitas menggunakan uji Barlet. Setelah melakukan pengujian persyaratan analisis, selanjutnya dilakukan pengujian ANAVA dua jalur, jika ternyata hasil hipotesis penelitian menyatakan ada interaksi selanjutnya dilakukan uji lanjut dengan menggunakan uji Scheffe bila jumlah sampel setiap sel berbeda atau uji Tuckey bila jumlah sampel setiap sel sama.

\section{Hipotesis Statistik}

Hipotesis statistik untuk penelitian ini adalah:

1. Hipotesis Pertama

$$
\begin{aligned}
& \mathrm{H}_{\mathrm{o}}: \mu \mathrm{A}_{1} \leq \mu \mathrm{A}_{2} \\
& \mathrm{H}_{\mathrm{a}}: \mu \mathrm{A}_{1}>\mu \mathrm{A}_{2}
\end{aligned}
$$

2. Hipotesis Kedua

$$
\begin{aligned}
& \mathrm{H}_{\mathrm{o}}: \mu \mathrm{B}_{1} \leq \mu \mathrm{B}_{2} \\
& \mathrm{H}_{\mathrm{a}}: \mu \mathrm{B}_{1}>\mu \mathrm{B}_{2}
\end{aligned}
$$

3. Hipotesis Ketiga

$$
\begin{aligned}
\mathrm{H}_{\mathrm{o}}: \mathrm{A}><\mathrm{B}=0 \\
\mathrm{H}_{\mathrm{a}}: \mathrm{A}><\mathrm{B} \neq 0
\end{aligned}
$$

\section{HASIL DAN PEMBAHASAN}

Pengujian hipotesis dilakukan dengan menggunakan teknik Analisis Varians (ANAVA). Untuk keperluan analisis varians, data - data yang diperlukan dapat ilihat pada Tabel 2, sedangkan data - data lengkap berada pada bagian lampiran penelitian ini.

Tabel 2. Rangkuman Data Hasil Penelitian

\begin{tabular}{|c|c|c|c|c|}
\hline \multirow{3}{*}{$\begin{array}{c}\text { Gaya } \\
\text { Belajar }\end{array}$} & \multirow{2}{*}{ Analisis } & \multicolumn{2}{|c|}{ Media Pembelajaran } & \multirow{2}{*}{ Total } \\
\cline { 2 - 5 } & & Animasi & Gambar Diam & \\
\hline \multirow{4}{*}{ Visual } & $\mathrm{N}=$ & 20 & 22 & 42 \\
\cline { 2 - 5 } & $\Sigma X=$ & 1610 & 1573 & 3183 \\
\cline { 2 - 5 } & $\Sigma X^{2}=$ & 130662 & 113775 & 244437 \\
\cline { 2 - 5 } & $\bar{X}=$ & 80,50 & 71,5 & 75,78 \\
\cline { 2 - 5 } & $\mathrm{S}=$ & 7,45 & 7,88 & 8,85 \\
\cline { 2 - 5 } & $\mathrm{S}^{2}=$ & 55,50 & 62,09 & 78,32 \\
\hline \multirow{4}{*}{ Auditori } & $\mathrm{N}=$ & 16 & 14 & 30 \\
\cline { 2 - 5 } & $\Sigma X=$ & 1170 & 997 & 2167 \\
\cline { 2 - 5 } & $\Sigma X^{2}=$ & 85908 & 71637 & 72,23 \\
\cline { 2 - 5 } & $\bar{X}=$ & 73,12 & 71,21 & 5,92 \\
\cline { 2 - 5 } & $\mathrm{S}=$ & 4,84 & 6,99 & \\
\hline
\end{tabular}




\begin{tabular}{|c|c|c|c|c|}
\hline \multirow{4}{*}{ Total } & $\mathrm{S}^{2}=$ & 23,43 & 48,86 & 35,0464 \\
\cline { 2 - 5 } & $\mathrm{N}=$ & 36 & 36 & 72 \\
\cline { 2 - 5 } & $\Sigma X=$ & 2780 & 2570 & 5350 \\
\cline { 2 - 5 } & $\Sigma X^{2}=$ & 216570 & 185412 & 401982 \\
\cline { 2 - 5 } & $\bar{X}=$ & 76,81 & 71,35 & 74,08 \\
\cline { 2 - 5 } & $\mathrm{S}=$ & 12,29 & 14,87 & 7,91 \\
\cline { 2 - 5 } & $\mathrm{S}^{2}=$ & 151,04 & 110,95 & 62,57 \\
\hline
\end{tabular}

Tabel 3. Hasil Perhitungan ANAVA

\begin{tabular}{|l|c|c|c|c|c|}
\hline \multicolumn{1}{|c|}{ Sumber Varians } & $\mathbf{d k}$ & $\mathbf{J K}$ & $\mathbf{R J K}$ & $\mathbf{F}_{\text {hitung }}$ & $\mathbf{F}_{\text {tabel }}$ \\
\hline $\begin{array}{l}\text { Media Pembelajaran } \\
\text { (Antar Kolom) }\end{array}$ & 1 & 612,49 & 612,49 & 12,430 & 4,01 \\
\hline $\begin{array}{l}\text { Gaya Belajar } \\
\text { (Antar Baris) }\end{array}$ & 1 & 220,84 & 220,84 & 4,482 & 4,01 \\
\hline Interaksi & 1 & 263,34 & 49,273 & 5,344 & 4,01 \\
\hline Galat & 68 & 1096,67 & 882,603 & & \\
\hline
\end{tabular}

Untuk menguji apakah hasil belajar IPS siswa yang dibelajarkan dengan media pembelajaran animasi berbeda dengan hasil belajar siswa yang dibelajarkan dengan media gambar diam, dilakukan dengan menggunakan teknik analisis varians (ANAVA). Berdasarkan pada bab III, pengujian dilakukan terhadap hipotesis statistik berikut :

$\mathrm{H}_{0}: \mu \mathrm{A}_{1} \leq \mu \mathrm{A}_{2}$

$\mathrm{H}_{\mathrm{a}}: \mu \mathrm{A}_{1}>\mu \mathrm{A}_{2}$

Pernyataan hipotesis tersebut adalah :

Ho : Hasil belajar IPS siswa yang dibelajarkan dengan media pembelajaran animasi lebih rendah atau sama dengan hasil belajar IPS siswa yang dibelajarkan dengan media gambar diam

Ha : Hasil belajar IPS siswa yang dibelajarkan dengan media pembelajaran animasi lebih tinggi dari hasil belajar IPS siswa yang dibelajarkan dengan media gambar diam

Dari hasil perhitungan dengan ANAVA yang ditunjukkan pada Tabel 4.14, diperoleh bahwa $\mathrm{F}_{\text {hitung }}=12,340$ dan $\mathrm{F}_{\text {tabel }}=4,01$ pada taraf signifikansi 0,05 . Hal ini berarti bahwa $F$ hitung $>\mathrm{F}_{\text {tabel }}$, menunjukkan bahwa hipotesis nol (Ho) ditolak dan hipotesis alternatif (Ha) diterima. Dengan demikian hipotesis penelitian yang menyatakan hasil belajar IPS siswa yang dibelajarkan dengan media pembelajaran animasi berbeda dengan hasil belajar IPS siswa yang dibelajarkan dengan media pembelajaran gambar diam.

Berdasarkan data yang diperoleh juga menunjukkan bahwa nilai rata - rata hasil belajar IPS siswa yang dibelajarkan dengan media pembelajaran animasi $(76,81)$ lebih tinggi dari hasil belajar IPS siswa yang dibelajarkan dengan media pembelajaran gambar diam $(71,35)$. Dari hasil perbandingan nilai rata - rata dan pengujian ANAVA yang diperoleh dapat disimpulkan bahwa hasil belajar IPS siswa yang dibelajarkan dengan media pembelajaran animasi berbeda dengan hasil belajar IPS siswa yang dibelajarkan dengan media gambar diam.

Pengujian apakah hasil belajar IPS siswa yang memiliki gaya belajar visual berbeda dengan hasil belajar IPS siswa yang memiliki gaya belajar auditori juga dilakukan dengan menggunakan teknik analisis varians (ANAVA). Berdasarkan bab III, pengujian dilakukan terhadap hipotesis statistik berikut :

$\mathrm{H}_{\mathrm{o}}: \mu \mathrm{B}_{1} \leq \mu \mathrm{B}_{2}$

$\mathrm{H}_{\mathrm{a}}: \mu \mathrm{B}_{1}>\mu \mathrm{B}_{2}$

Pernyataan hipotesis tersebut adalah :

Ho : Hasil belajar IPS siswa yang memiliki gaya belajar visual lebih rendah atau sama dengan hasil belajar IPS siswa yang memiliki gaya belajar auditori

$\mathrm{Ha}$ : Hasil belajar IPS siswa yang memiliki gaya belajar visual lebih tinggi dari hasil belajar IPS siswa yang memiliki gaya belajar auditori

Dari hasil perhitungan dengan ANAVA yang ditunjukkan pada Tabel 4.14, diperoleh bahwa $\mathrm{F}_{\text {hitung }}=4,482$ dan $\mathrm{F}_{\text {tabel }}=4,01$ pada taraf signifikansi 0,05 . Hal ini berarti bahwa $F$ hitung $>\mathrm{F}_{\text {tabel }}$, menunjukkan bahwa hipotesis nol (Ho) ditolak dan hipotesis alternatif (Ha) diterima. Dengan demikian hipotesis penelitian yang menyatakan hasil belajar IPS siswa yang 
memiliki gaya belajar visual berbeda dengan hasil belajar IPS siswa yang memiliki gaya belajar auditori.

Berdasarkan data yang diperoleh juga menunjukkan bahwa nilai rata - rata hasil belajar IPS siswa memiliki gaya belajar visual $(122218,5)$ lebih tinggi dari hasil belajar IPS siswa yang dibelajarkan dengan media pembelajaran gambar diam $(78772,5)$. Dari hasil perbandingan nilai rata - rata dan pengujian ANAVA yang diperoleh dapat disimpulkan bahwa hasil belajar IPS siswa yang memiliki gaya belajar visual berbeda dengan hasil belajar IPS siswa yang memiliki gaya belajar auditori.

Pengujian ada tidaknya interaksi antara media pembelajaran dengan gaya belajar terhadap hasil belajar siswa juga dengan menggunakan teknik analisis varians (ANAVA). Berdasarkan bab III pengujian dilakukan terhadap hipotesis berikut :

$\mathrm{H}_{\mathrm{o}}: \mathrm{A}><\mathrm{B}=0$

$\mathrm{H}_{\mathrm{a}}: \mathrm{A}><\mathrm{B} \neq 0$

Pernyataan hipotesis tersebut adalah :
Ho : Tidak terdapat interaksi antara media pembelajaran dan gaya belajar terhadap hasil belajar IPS siswa

Ha : Terdapat interaksi antara media pembelajaran dan gaya belajar terhadap hasil belajar IPS siswa

Dari hasil perhitungan dengan ANAVA yang ditunjukkan pada Tabel 4.14, diperoleh bahwa $\mathrm{F}_{\text {hitung }}=5,344$ dan $\mathrm{F}_{\text {tabel }}=4,01$ pada taraf signifikansi 0,05 . Hal ini berarti bahwa $\mathrm{F}$ hitung $>\mathrm{F}_{\text {tabel }}$, menunjukkan bahwa hipotesis nol (Ho) ditolak dan hipotesis alternatif (Ha) diterima. Dengan demikian hipotesis penelitian yang menyatakan bahwa terdapat interaksi antara media pembelajaran dan gaya belajar terhadap hasil belajar IPS siswa teruji kebenarannya.

Berdasarkan hasil pengujian hipotesis diatas dapat juga dilihat bahwa ada interaksi antara media pembelajaran dan gaya belajar terhadap hasil belajar siswa. Interaksi tersebut dapat dilihat pada Gambar 1 berikut :

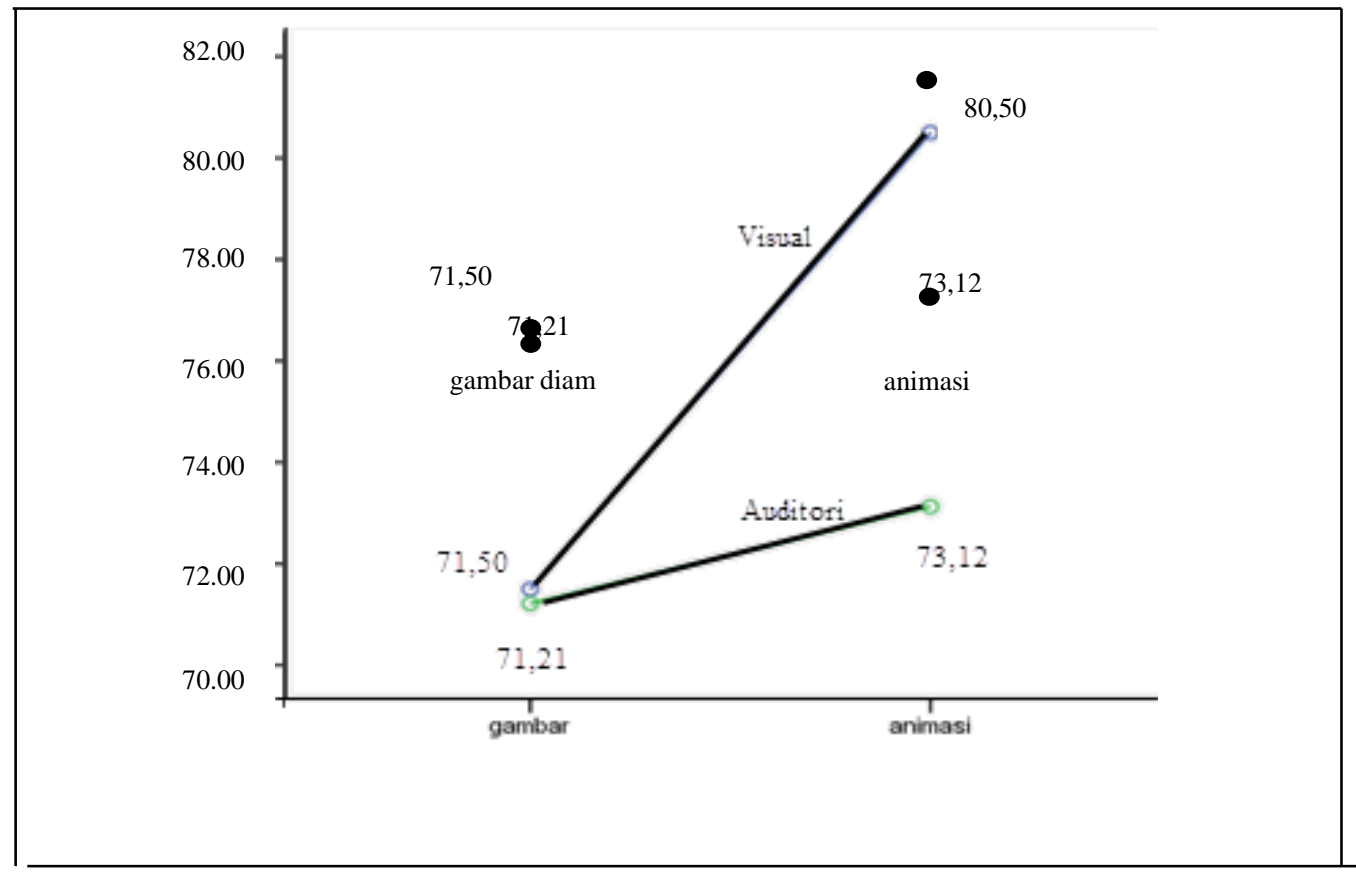

Gambar 1. Interaksi antara media pembelajaran dan gaya belajar dalam mempengaruhi hasil belajar IPS siswa maka perlu diadakan uji lanjut dengan menggunakan uji Tuckey.

Tabel 4. Ringkasan Hasil Perhitungan Uji Lanjut (Uji Tuckey)

\begin{tabular}{|c|c|c|}
\hline Nilai Kelompok Yang & \multirow{2}{*}{$\mathrm{F}_{\text {hitung }}$} & $\mathrm{F}_{\text {tabel }}$ \\
\cline { 3 - 3 } Dibandingkan & 11,62461 & $\alpha=0,05$ \\
\hline$\mu_{11}$ dengan $\mu_{12}$ & 2,83 \\
\hline$\mu_{11}$ dengan $\mu_{21}$ & 12,67137 & 2,83 \\
\hline$\mu_{11}$ dengan $\mu_{22}$ & 10,57784 & 2,83 \\
\hline
\end{tabular}




\begin{tabular}{|c|r|r|}
\hline$\mu_{21}$ dengan $\mu_{22}$ & 1,046766 & 2,83 \\
\hline$\mu_{21}$ dengan $\mu_{12}$ & 1,046766 & 2,83 \\
\hline$\mu_{12}$ dengan $\mu_{22}$ & 2,093531 & 2,83 \\
\hline
\end{tabular}

Keterangan :

$\mu_{11}:$ Rata-rata nilai hasil belajar IPS siswa yang dibelajarkan dengan menggunakan media pembelajaran animasi dan memiliki gaya belajar visual

$\mu_{12}$ : Rata - rata nilai hasil belajar IPS siswa yang dibelajarkan dengan menggunakan media pembelajaran animasi dan memiliki gaya belajar auditori

$\mu_{21}$ : Rata - rata nilai hasil belajar IPS siswa yang dibelajarkan dengan menggunakan media pembelajaran gambar diam dan memiliki gaya belajar visual

$\mu_{22}$ : Rata - rata nilai hasil belajar IPS siswa yang dibelajarkan dengan menggunakan media pembelajaran gambar diam dan memiliki gaya belajar auditori.

Kriteria penerimaan, jika $F_{\text {hitung }}>F_{\text {tabel }}$,

maka ada perbedaan yang signifikan. Dari hasil uji Tuckey diatas diperoleh kesimpulan :

a. Rata - rata nilai hasil belajar IPS yang dibelajarkan dengan media pembelajaran animasi dan memiliki gaya belajar visual lebih baik jika dibandingkan dengan rata rata nilai hasil belajar IPS yang dibelajarkan dengan media pembelajaran animasi dan memiliki gaya belajar auditori.

b. Rata - rata nilai hasil belajar IPS yang dibelajarkan dengan media pembelajaran animasi dan memiliki gaya belajar visual lebih baik jika dibandingkan dengan rata-rata nilai hasil belajar IPS yang dibelajarkan dengan media pembelajaran gambar diam dan memiliki gaya belajar visual.

c. Rata - rata nilai hasil belajar IPS yang dibelajarkan dengan media pembelajaran animasi dan memiliki gaya belajar visual lebih baik jika dibandingkan dengan rata rata nilai hasil belajar IPS yang dibelajarkan dengan media pembelajaran gambar diam dan memiliki gaya belajar auditori

d. Rata - rata nilai hasil belajar IPS yang dibelajarkan dengan media pembelajaran gambar diam dan memiliki gaya belajar visual tidak lebih baik jika dibandingkan dengan rata - rata nilai hasil belajar IPS yang dibelajarkan dengan media pembelajaran gambar diam dan memiliki gaya belajar auditori

e. Rata - rata nilai hasil belajar IPS yang dibelajarkan dengan media pembelajaran gambar diam dan memiliki gaya belajar visual tidak lebih baik jika dibandingkan dengan rata - rata nilai hasil belajar IPS yang dibelajarkan dengan media pembelajaran animasi dan memiliki gaya belajar auditori

f. Rata - rata nilai hasil belajar IPS yang dibelajarkan dengan media pembelajaran animasi dan memiliki gaya belajar visual lebih baik jika dibandingkan dengan rata-rata nilai hasil belajar IPS yang dibelajarkan dengan media pembelajaran gambar diam dan memiliki gaya belajar auditori.

\section{Pembahasan}

Media pembelajaran animasi menghasilkan peningkatan pemahaman dalam pengetahuan, lebih berpikir kreatif, memperoleh keterampilan untuk memperoleh dan menganalisis informasi, membangun konsep, dan kemudian menghasilkan dan penjelasan tes atau teori . Para siswa akan aktif terlibat dalam eksplorasi, bertanya, pemecahan masalah, penalaran induktif karena pembelajaran dengan menggunakan media animasi membawa siswa langsung melihat materi pembelajaran secara nyata.

Hal ini akan meningkatkan pemahaman ilmu pengetahuan, produktivitas dalam berpikir kreatif, dan keterampilan-keterampilan dalam memperoleh dan menganalisis informasi. Media pembelajaran animasi adalah upaya pengembangan para pembelajar yang mandiri, metodenya mensyaratkan partisipasi aktif siswa dalam pembelajaran. Siswa sebenarnya memiliki rasa ingin tahu dan hasrat yang besar untuk tumbuh berkembang. Media pembelajaran animasi memanfaatkan eksplorasi kegairahan alami siswa, memberikan siswa arahan-arahan khusus sehingga siswa dapat mengeksplorasi bidang-bidang baru secara efektif. Dalam pembelajaran menggunakan media animasi, siswa diajak menyaksikan langsung suatu pengalaman atau kejadian yang dialami siswa dalam kehidupannya sehari-hari. Dari penelaahan kejadian - kejadian tersebut, terbangun bentuk pengetahuan dalam pemikiran 
siswa.

Peran guru sebagai motivator terlihat jelas
saat guru mengajak siswa untuk mengidentifikasi dan merumuskan masalah. Sebagai fasilitator guru memberi ruang kepada siswa melakukan diskusi dengan sesama teman, guru memberi ruang kepada siswa melakukan tanya jawab dan memberi kesempatan siswa memaparkan hasil diskusinya. Serangkaian kegiatan pembelajaran yang dilakukan siswa dengan semangat dan mampu membangun struktur kognitif dalam memori jangka panjang. Hasil belajar siswa pun menjadi lebih baik.

Pandangan konstruktivis prinsip yang paling penting dalam psikologi pendidikan adalah bahwa guru tidak hanya sekedar memberikan pengetahuan kepada siswa dikira tepat menguatkan temuan pada penelitian ini. Guru sebagai fasilitator pembelajaran dan merancang pembelajaran dimana siswa lah yang melakukan pembelajaran tersebut.

Teori perkembangan kognitif yang turut mendukung media pembelajaran animasi adalah teori Vhygotsky. Ada dua konsep yang sangat penting dalam teori Vhygotsky yaitu Zone Proximal Development (ZPD) dan Scaffolding. ZPD merupakan jarak antara tingkat pengembangan aktual yang didefenisikan sebagai kemampuan pemecahan masalah secara mandiri dengan tingkat pengembangan potensial dimana kemampuan pemecahan masalah tersebut dibawah bimbingan orang dewasa atau melalui kerjasama dengan teman sebaya yang kemampuannya lebih tinggi. Guru berperan melakukan bimbingan kepada siswa dalam merumuskan suatu permasalahan. Kemudian melakukan Scaffolding yang merupakan pemberian sejumlah bantuan kepada siswa selama tahap-tahap awal pembelajaran, kemudian mengurangi bantuan dan memberikan kesempatan pada siswa untuk mengambil alih tanggung jawab yang semakin besar setelah dia dapat melakukannya. Guru melakukan pengamatan terhadap aktivitas siswa seperti diskusi dan menyimpulkan pembelajaran. Proses pengambilan keputusan diberikan penuh kepada siswa, guru hanya sebagai motivator agar semangat siswa dalam melakukan pembelajaran tetap terjaga dan menjadi inspirator agar muncul ide/gagasan yang kreatif dalam penarikan kesimpulan siswa.

Berbeda halnya dengan media pembelajaran gambar diam yang mengedepankan proses latihan kepada siswa. Pengetahuan diajarkan dengan dengan cara melatih siswa, kecenderungan siswa dituntut menghapal pengetahuan yang diberikan guru. Serangkaian kegiatan dilakukan secara instruksional tanpa memberi kesempatan siswa mencari sendiri pengetahuannya. Serangkaian kegiatan pembelajaran ini mengkondisikan pada situasi kelas yang diam, tanpa aktivitas siswa, tanpa kegiatan tanya jawab dan siswa hanya memperhatikan penjelasan guru. Kegiatan siswa yang pasif tersebut berdampak kepada lemahnya penyerapan pengetahuan oleh siswa. Pengetahuan yang diperoleh tidak bertahan lama dalam memori siswa, sehingga hasil belajar siswa pun menjadi rendah.

Hasil belajar siswa yang diajarkan dengan media pembelajaran animasi menunjukan hasil yang baik. Siswa mampu menjawab tes hasil belajar pada semua ranah kognitif dengan baik. Berbeda jika dibandingkan dengan hasil belajar siswa yang diajarkan dengan media pembelajaran gambar diam yang memperoleh hasil belajar yang lebih rendah.

Maka dapat disimpulkan bahwa terdapat perbedaan hasil belajar antara siswa yang diajarkan dengan media pembelajaran animasi dan gambar diam dimana hasil belajar siswa yang diajarkan dengan media pembelajaran animasi $(76,81)$ lebih tinggi dari hasil belajar siswa yang diajarkan dengan media pembelajaran gambar diam $(71,35)$.

Kesimpulan di atas senada dengan hasil penelitian sebelumnya yang dilakukan oleh Emelda Marzuki (2008) yang menyatakan bahwa penggunaan animasi multimedia memiliki pengaruh yang signifikan dengan penguasaan materi IPS siswa. Begitu juga penelitian relevan yang dilakukan oleh Puryaningsih (2008) yang menyatakan bahwa hasil belajar siswa yang dibelajarkan menggunakan media animasi lebih tinggi daripada siswa yang dibelajarkan tanpa menggunakan media animasi. Secara umum perbedaan yang melandasi hasil penelitian ini dengan penelitian sebelumnya adalah pada penelitian ini digunakan variabel gaya belajar dimana disimpulkan bahwa untuk menerapkan media pembelajaran animasi maka guru haruslah mempertimbangkan gaya belajar yang dimiliki oleh siswa.

Berdasarkan hasil perhitungan dalam penelitian yang diperoleh, terlihat bahwa hasil belajar IPS siswa yang memiliki gaya belajar visual lebih tinggi jika dibandingkan dengan hasil belajar IPS siswa yang memiliki gaya belajar auditori. Bagi siswa yang memiliki gaya 
belajar visual akan memiliki kemampuan berpikir yang baik untuk melihat dan menangkap informasi secara visual sebelum ia memahaminya. Siswa yang memiliki gaya belajar visual memiliki kepekaan yang kuat terhadap warna, disamping mempunyai pemahaman yang cukup terhadap masalah artistik.

Siswa mampu memperoleh pemikiran yang logis, rasional dan abstrak. Siswa yang berada pada tahap ini telah mampu mempertimbangkan berbagai pandangan secara simultan dan memandang tindakannya secara obyektif. Siswa dengan pemikiran logisnya mampu menyelesaikan permasalahan dengan solusi yang tepat. Pengetahuan siswa juga lebih terarah. Siswa juga mampu mengabstraksi hasil diskusi terhadap pemecahan masalah sehingga dapat dikatakan siswa dengan gaya belajar visual memperoleh hasil belajar yang baik.

Berbeda halnya jika siswa memiliki gaya belajar auditori. Siswa cenderung monoton dalam menyelesaikan suatu permasalahan. Siswa tidak mampu bekerja secara mandiri karena ketergantungan akan petunjuk dari guru membuat siswa lambat dalam melakukan pembelajarannya sendiri. Kesulitan dalam mengabstraksikan hasil pembelajaran siswa ini dikarenakan siswa sulit menggunakan logikanya dalam menyelesaikan permasalahan pada materi pembelajaran. Sehingga dapat dikatakan siswa dengan gaya belajar auditori memperoleh hasil belajar yang kurang baik.

Maka dapat disimpulkan bahwa terdapat perbedaan hasil belajar antara siswa yang memiliki gaya belajar visual dan gaya belajar auditori, dimana hasil belajar siswa yang memiliki gaya belajar visual $(75,78)$ lebih tinggi dari siswa yang memiliki gaya belajar auditori $(72,23)$.

Dari hasil penelitian ditemukan bahwa media pembelajaran dan gaya belajar saling berinteraksi dalam mempengaruhi hasil belajar IPS siswa. Dari hasil perhitungan diperoleh $\mathrm{F}$ hitung $=5,344$ dan $\mathrm{F}_{\text {tabel }}=4,01$. Dan setelah dilakukan uji lanjut (uji Tuckey), terdapat interaksi yang menunjukkan bahwa nilai $\mu_{11}$ dengan $\mu_{22}(10,57)$ lebih tinggi dari $\mathrm{F}_{\text {tabel }}$ $(2,83)$. Hal tersebut sesuai dengan tujuan media pembelajaran animasi yaitu mempermudah siswa dalam memahami materi pembelajaran.

Sedangkan bagi siswa yang memiliki gaya belajar visual cenderung memiliki kemampuan berpikir yang baik untuk melihat dan menangkap informasi secara visual sebelum ia memahaminya. Siswa yang memiliki gaya belajar visual memiliki kepekaan yang kuat terhadap warna, disamping mempunyai pemahaman yang cukup terhadap masalah artistik.

Siswa yang memiliki gaya belajar visual diajarkan dengan media pembelajaran animasi lebih tepat untuk mereduksi hasil-hasil belajar yang sebelumnya terdapat dalam pengetahuannya. Selain itu siswa juga mampu berkoordinasi dengan teman dalam kelompoknya. Siswa mampu menuangkan pengetahuannya yang mendukung proses diskusi dengan teman kelompok, sehingga memperoleh hasil belajar yang tinggi. Namun jika diberikan dengan pembelajaran menggunakan media gambar diam justru akan berpengaruh negatif. Siswa cenderung pasif, tidak dapat melakukan koordinasi dalam pembelajarannya.

Sedangkan bagi siswa yang memiliki gaya belajar auditori kurang mampu berinteraksi bila diajarkan dengan media gambar diam. Media pembelajaran animasi berupaya untuk dapat mengkonstruksi suatu kejadian atau pengalaman yang berkaitan dengan materi pembelajaran berupa objek dengan memandangnya melalui suatu kerangka logis yang mentransformasi, mengorganisasi dan menginterpretasi suatu pengetahuan. Siswa yang memiliki gaya belajar auditori akan mengalami banyak kendala, sehingga bila diberikan media pembelajaran animasi akan kurang tepat dan berpengaruh negatif terhadap hasil belajar siswa. Dengan demikian siswa yang mempunyai gaya belajar auditori akan lebih baik bila diajarkan dengan media gambar diam. Jadi dapat disimpulkan bahwa pada media pembelajaran animasi dan gaya belajar visual mempengaruhi hasil belajar.

\section{PENUTUP}

\section{Simpulan}

1. Terdapat perbedaan hasil belajar siswa yang dibelajarkan dengan media pembelajaran animasi dan media pembelajaran gambar diam. Hasil belajar siswa yang diajarkan dengan media pembelajaran animasi lebih baik dari hasil belajar siswa yang diajarkan dengan media pembelajaran gambar diam.

2. Terdapat perbedaan hasil belajar siswa yang mempunyai gaya belajar visual dan gaya belajar auditori. Hasil belajar siswa yang mempunyai gaya belajar visual lebih baik dari hasil belajar siswa yang mempunyai gaya belajar auditori. 
3. Terdapat interaksi antara media pembelajaran dan gaya belajar terhadap hasil belajar siswa dimana yang diajarkan dengan media pembelajaran animasi dipengaruhi oleh gaya belajar, sedangkan yang diajarkan dengan media pembelajaran gambar diam tidak dipengaruhi gaya belajar siswa.

\section{Saran}

Berdasarkan hasil pada penelitian ini, maka peneliti memiliki beberapa saran yaitu sebagai berikut:

1. Dalam penerapan media pembelajaran animasi guru harus memperhatikan gaya belajar siswa, karena media pembelajaran animasi ini tepat untuk siswa yang memiliki gaya belajar visual.

2. Untuk siswa yang memiliki gaya belajar auditori disarankan untuk tidak diajarkan dengan media pembelajaran animasi karena siswa akan kesulitan dalam melakukan proses pembelajaran, siswa sulit menganalisis materi pembelajaran yang dilakukan siswa selama proses pembelajaran.

3. Disarankan kepada peneliti lanjutan, kiranya dapat melanjutnya penelitian ini dengan menerapkan media pembelajaran animasi yang lebih kreatif dalam proses pembelajaran untuk meningkatkan hasil belajar siswa. Selain itu, peneliti lanjutan haruslah mempertimbangkan penggunaan waktu yang diperlukan dalam memberikan materi pembelajaran agar pembelajaran dapat berlangsung efektif dan efisien.

4. Bagi pengelola lembaga pendidikan, perlu kiranya mengadakan pelatihan kepada guruguru mengenai cara membuat dan merancang media pembelajaran animasi agar pembelajaran yang dilakukan sesuai dengan kondisi yang dibutuhkan siswa.

\section{DAFTAR PUSTAKA}

Ahmadi, A. 2003. Psikologi Umum. Jakarta : Rineka Cipta

Anderson, O.W. dan Krathwohl, D.R. 2001. A Taxonomy for Learning Teaching and Assesning. New York: Addison Wesley Longman

Arief S. Sadiman, dkk. 2009. Media Pendidikan, Pengertian, Pengembangan, dan. Pemanfaatannya. Jakarta: Rajawali Press

Arikunto, Suharsimi. 2009 (Edisi Revisi). Prosedur Penelitian Suatu Pendekatan Praktik. Jakarta : Rineka Cipta.
Arsyad, Azhar. 2002. Media Pembelajaran. Jakarta: Rajagrafindo Persada

Asri, Budiningsih. 2005. Belajar dan Pembelajaran. Jakarta: Rineka Cipta

Bloom, Benjamin .S. Gf. Madausan d. J. T Hesting. 1965. Evaluation to Imprpve Learning. New York : Mc Gran Hill Book Company.

Briggs, M. L. 1982. Learning Theories For Teachers. New York : Harper \& Row.

Degeng, N.S. 2000. Pedoman Penyusunan Bahan Ajar. Lembaga Pengembangan Pendidikan dan Pembelajaran (LP3). Universitas Negeri Malang.

De Porter, B., Mike Hernacki. 2004. Quantum Learning. Bandung: Kaifa

Gagne, R.M 1985. The Conditions of Learning and Theory of Instruction $\left(4^{\text {th }} e d\right)$. Orlando : Holt, Rinehart, and Winston.

Hasan, Helmi dkk. 2003. Buku Ajar Strategi Belajar Mengajar, Padang: UNP.

Heinich R., Molenda M., \& Russel J.D. 1990. Instructional Media and The Technologies of Instruction (third ed). New York. Med Millan

Joyce Bruce and Weil Marsha. 1986. Models Of Teaching. New Delhi. Prentice Hall.

Kemp, J, E. 1994. The Intructional Design Process: A Plan for Unit and Course Development. California: Fearon Publishers, Inc.

Munadi, Yudhi. 2008. Media Pembelajaran, Sebuah Pendekatan Baru. Jakarta: Gaung Persada Press.

Nasution, S. 2002. Berbagai Pendekatan dalam Proses Belajar Mengajar. Bandung: Bumi Aksara

Prasnig, Barbara. 2007. The Power of Learning Style. Bandung : Kaifa

Reigeluth, C. M. 1983. Instructional Design Theory of Models : An Overview of Their Current Status. London : Prentice Hall

Romiszwoski, AJ. 1981. Instructional Design System, Decision Making in Course Planning and Curriculum Design. London: Prentice Hall

Rusman. 2012. Model-Model Pembelajaran: Mengembangkan Profesionalisme Guru. Jakarta: Rajawali Pers.

Sabri, Ahmad. 2007. Strategi Belajar Mengajar \& Micro Teaching. Jakarta: Quantum Teaching.

Sagala,T. 2005. Konsep dan Makna Pembelajaran, Bandung: alfabet 
Sanjaya, Wina. 2008. Perencanaan dan Desai Sistem Pembelajaran. Jakarta: Kencana Prenada Media Group.

Strategi Pembelajaran Berorientasi Standar Proses Pendidikan, Jakarta: Kencana Prenada Media Group

Sudijono, Anas. 2009. Pengantar Statistik Pendidikan. Jakarta : Rajagrafindo Persada.

Sudjana. 2002.Metode Statistik.Bandung: Tarsito

Trianto. 2007. Model Pembelajaran Terpadu Dalam Teori dan Praktek. Jakarta: Prestasi Pustaka Publisher.

Widodo, S. Chomsin, dkk, 2008. Panduan Menyusun Bahan Ajar. Jakarta : PT. Elex Media Komputindo. 